\title{
Chronic partial urethral obstruction in female rats. Description of an experimental model and initial results ${ }^{1}$
}

\author{
Obstrução parcial uretral crônica em ratos. Descrição de um modelo experimental e resultados \\ iniciais
}

\begin{abstract}
Silvio Tucci Jr', Carlos Augusto Ferreira Molina"I, Marcelo Ferreira Cassinii", Murilo Ferreira de Andrade ${ }^{\mathrm{II}}$, Gilson José de Lima ${ }^{I I I}$, Antonio Carlos Pereira Martins ${ }^{\text {IV }}$

IAssociate Professor, Urology Division, Department of Surgery and Anatomy, FMRP-USP, Ribeirao Preto-SP, Brazil. Substantial contributions to conception and design, acquisition of data, analysis and interpretation of data.

IIAssistant Professor, Urology Division, Department of Surgery and Anatomy, FMRP-USP, Ribeirao Preto-SP Brazil. Substantial contributions to conception and design, acquisition of data, analysis and interpretation of data.

IIIMD, Division of Urology, Department of Surgery and Anatomy, FMRP-USP, Ribeirao Preto-SP, Brazil. Drafting the article or revising it critically for important intellectual content.

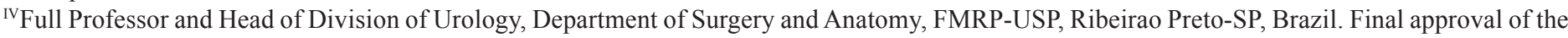
version to be published.
\end{abstract}

\begin{abstract}
PURPOSE: To develop an experimental model of infravesical urinary obstruction in female rats.

METHODS: After median caudal laparotomy, the urethra of 14 female rats was delicately separated from the vagina and loosely wrapped with cellophane tape measuring $0.4 \times 1.0 \mathrm{~cm}$. The animals were evaluated $4(\mathrm{n}=7)$ and $8(\mathrm{n}=7)$ weeks later. Five additional control animals were only subjected to separation of the urethra and vagina and monitored for 12 weeks.

RESULTS: After four weeks, three rats presented vesical dilation associated with discrete ureteral ectasis in 2 animals, with the third presenting discrete hydronephrosis in one kidney. After eight weeks, five rats $(71.4 \%)$ presented vesical distension with bilateral ureterohydronephrosis. No significant changes $(p>0.05)$ in serum urea or creatinine occurred in any group compared to preoperative values.

CONCLUSION: We present here an inexpensive and simple method for the slow induction of urethral obstruction in adult female rats, with the development of progressive vesical hypertrophy and ureterohydronephrosis, which may be used as an experimental model for the study of different aspects of obstructive nephropathy.
\end{abstract}

Key words: Urethral Obstruction. Urinary Bladder. Rats.

\section{RESUMO}

OBJETIVO: Desenvolver modelo experimental de obstrução urinária infravesical em ratas.

MÉTODOS: Após laparotomia caudal mediana, as uretras de 14 ratas foram delicadamente separadas da vagina e frouxamente envoltas com fita de celofane medindo $0.4 \times 1.0 \mathrm{~cm}$. Os animais foram avaliados $4(\mathrm{n}=7)$ e $8(\mathrm{n}=7)$ semanas depois. Cinco animais adicionais (controle) foram submetidos apenas à separação da uretra e da vagina e monitoradas por 12 semanas.

RESULTADOS: Após quatro semanas, três ratas apresentaram dilatação vesical associada a discreta ectasia ureteral em 2 animais, com o terceiro apresentando discreta hidronefrose em um rim. Após oito semanas, cinco ratas (71.4\%) apresentaram distensão vesical com ureterohidronefrose bilateral. Não ocorreram alterações significativas ( $>0.05)$ nos valores de uréia ou creatinina em qualquer grupo, comparado com valores pré-operatórios.

CONCLUSÃO: Apresentamos aqui um método barato e simples para a indução lenta de obstrução uretral em ratas adultas, com desenvolvimento progressivo de hipertrofia vesical e ureterohidronefrose, podendo ser utilizado como modelo experimental para estudo de diferentes aspectos da nefropatia obstrutiva.

Descritores: Obstrução Uretral. Bexiga Urinária. Ratos. 


\section{Introduction}

Infravesical obstruction implies numerous functional changes in the middle and upper urinary tract, eventually reaching chronic renal insufficiency as an extreme result. Thus, animal models of urine flow obstruction provide the opportunity to study the most varied aspects of this clinical condition so frequently occurring in humans. In addition to changes in the renal parenchyma, there are also functional changes in the bladder secondary to muscle hypertrophy, such as vesical hyperactivity ${ }^{1,2}$. Most experimental models of urethral obstruction are conditioned to partial urethra ligation in adult animals or to the positioning of a periurethral ring $^{3}$.

We present here the initial results of an experimental model of chronic infravesical obstruction using adult animals.

\section{Methods}

Nineteen female Wistar rats weighing 270 to $310 \mathrm{~g}$ were used. The animals were provided by the Animal House of the Faculty of Medicine of Ribeirão Preto, University of São Paulo.

The procedures were carried out under general anesthesia induced with a combination of Ketamine ${ }^{\circledR}$ and Xylazine ${ }^{\circledR}$ administered by the intramuscular route. After shaving and antisepsis of the abdominal skin with an iodine solution, caudal medial laparotomy measuring about $2 \mathrm{~cm}$ in length was performed for exposure of the bladder and urethra. Using a microsurgery forceps, the urethra and vagina were delicately separated for an extension of 5 to $7 \mathrm{~mm}$. In 14 animals the urethra was loosely wrapped with cellophane tape measuring $0.4 \mathrm{~cm}$ in width and 1.0 $\mathrm{cm}$ in length, kept in place with a single non-absorbable monofilament suture transfixing only its extremities (Figure 1). The incision was closed on two planes and the animals were kept in cages with free access to water and ration.

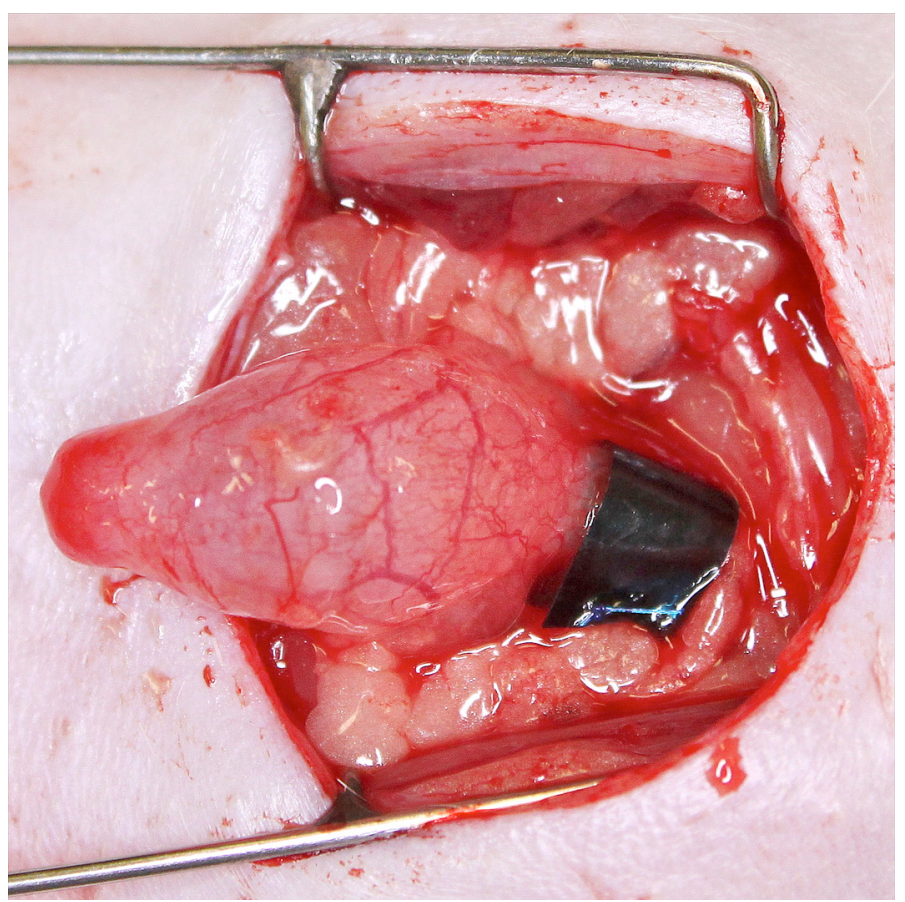

FIGURE 1 - cellophane tape loosely fixed around the urethra.
The animals that received the periurethral cellophane tape were divided into two groups of 7 animals each which differed in terms of the length of postoperative observation (group A - 4 weeks; group B -8 weeks). The remaining five animals, only submitted to separation of the urethra from the vagina, were used as controls and kept in cages for a period of 12 weeks.

Blood samples were obtained from all animals for the determination of serum urea and creatinine preoperatively and at the time of sacrifice. At the end of the observation period the animals were again anesthetized and the urinary tract was examined for macroscopic changes, with kidney, ureters, bladder and urethra being removed en bloc. Fragments of the vesical wall were stained with hematoxylin-eosin for analysis by light microscopy.

Serum urea and creatinine values were analyzed statistically by the Kruskal-Wallis test.

\section{Results}

All animals survived the initial procedure. In group A, evaluated after four weeks of follow-up, three rats showed vesical dilation associated with discrete ureteral ectasis in two and with discrete hydronephrosis in one renal unit. The other animals showed no changes in the urinary tract. In group B, evaluated eight weeks after surgery, five rats $(71.4 \%)$ showed vesical distension with ureterohydronephrosis. Vesical distension was easily visualized at inspection before the opening of the abdominal cavity (Figure 2).

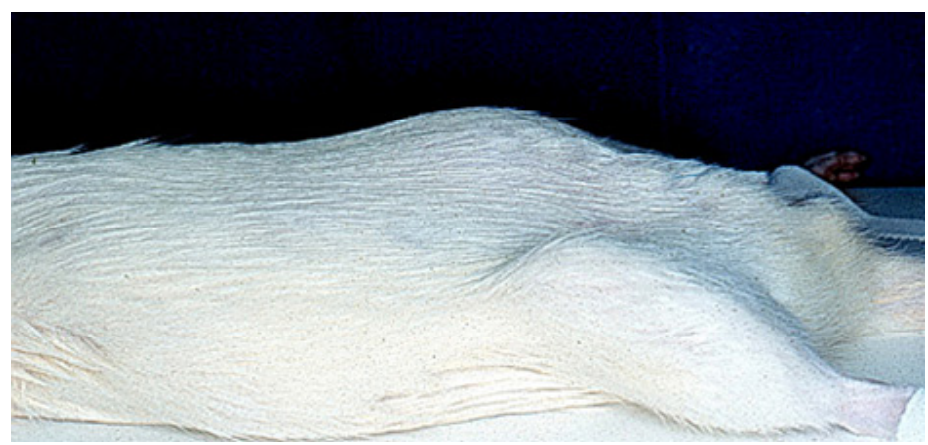

FIGURE 2 - Bladder distension after 8 weeks.

After en bloc removal of the urinary tract, the anterior wall of the bladder was opened and a polyethylene catheter was introduced through the bladder neck and easily exteriorized through the urethra, revealing urethral permeability despite the local obstructive process (Figure 3 ). Control animals evaluated 12 weeks after surgery showed no macroscopic anatomical changes in the urinary tract. There were no significant changes $(p>0.05)$ in serum urea or creatinine values in any of the three groups compared to preoperative values (Table 1). 


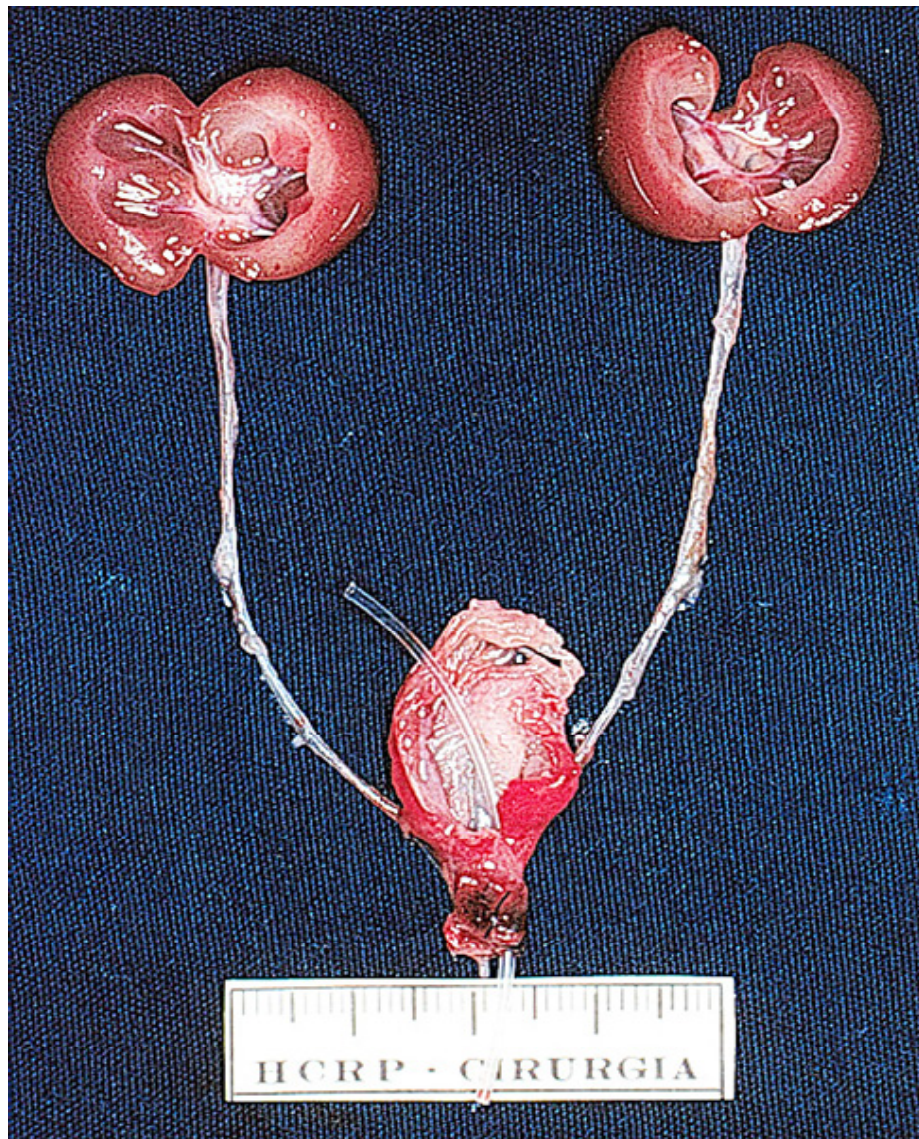

FIGURE 3 - Ureterohydronephrosis and bladder distension after 8 weeks.

TABLE 1 - Mean serum urea and creatinine values in the different groups.

\begin{tabular}{ccc}
\hline Preoperative & urea $(\mathbf{m g} / \mathbf{\%})$ & creatinine $(\mathbf{m g} / \mathbf{\%})$ \\
\hline Control & 48.5 & 0.55 \\
Group A & 54.9 & 0.54 \\
Group B & 55.5 & 0.68 \\
& & \\
\hline Postoperative & urea $(\mathbf{m g} \%)$ & creatinine $(\mathbf{m g} \%)$ \\
\hline Control & 49.5 & 0.57 \\
Group A & 53.2 & 0.55 \\
Group B & 54.1 & 0.58 \\
\hline
\end{tabular}
hypertrophy.

The histological study confirmed the presence of detrusor

\section{Discussion}

Cellophane has been reported to be able to induce an inflammatory process causing intense local connective tissue deposition. This has led to the creation of an experimental model of arterial hypertension in which the kidney is fully wrapped with this material ${ }^{4,5}$. In another study, the use of a cellophane tape loosely wrapping the ureter caused a progressive development of experimental hydronephrosis with signs and symptoms similar to those of ureteropyelic junction stenosis ${ }^{6,7}$.

In the present study, $74.1 \%$ of the animals showed macroscopic evidence of urinary flow obstruction characterized by vesical distension and ureterohydronephrosis, although without changes in serum urea or creatinine levels during the postoperative follow-up of 8 weeks. This last fact was probably due to the short period of observation.

Detrusor hypertrophy was clearly visible by macroscopic observation and could be quantified and properly studied by histological analysis (not shown here). Because of the characteristics of the method, the degree of urethral obstruction may vary in each animal, possibly resulting in detrusor hypertrophy and hydronephrosis of different intensities for the same period of observation. This should not be an obstacle to the use of this technique in experimental studies since other methods also do not always permit a proportional obstruction. However, to bypass this situation, a catheter could be place externally to the urethra just at the time of fixation of the cellophane band.

Particularly important was the intensity of the local inflammatory process, with deposition of connective tissue causing urethral obstruction. However the periurethral tape can be removed if proper caution is used. The inflammatory process leads to extrinsic compression of the urethra but permits passage of the catheter through its lumen. The macroscopic data obtained for the control group support the importance of the inflammatory process as a cause of obstruction since simple separation between the urethra and vagina did not cause macroscopic changes in the urinary tract or changes in serum urea and creatinine even after a longer period of postoperative follow-up.

Despite the intensity of vesical distension observed in some animals, spontaeous micturition episodes still occurred in these animals.

Finally this method showed positive results only when applied to females, whereas it was not possible to promote obstruction in males.

\section{Conclusion}

We have presented here a very inexpensive and simple model of slow and progressive urethral obstruction in adult female rats with development of progressive vesical hypertrophy and ureterohydronephrosis, which may serve as an experimental model for the study of different aspects of obstructive nephropathy. 


\section{References}

1. O'Connor Jr LT, Vaughan Jr ED, Felsen D. In vivo cystometric evaluation of progressive bladder outlet obstruction in rats. J Urol. 1997; 158:631-5.

2. Polido Jr A, Costa JM, Munhoz T, Sampaio FJ, Cardoso LE, Amaro JL. Intravesical oxybutynin protects the vesical wall against functional and smooth muscle changes in rabbits with detrusor overactivity. Int Urogynecol J Pelvic Floor Dysfunct. 2010;21:1539-44.

3. Li YD, Song HY, Kim JH, Woo CW, Park JH, Kim TH, Gong G. Evaluation of formation of granulation tissue caused by metallic stent placement in a rat urethral model. J Vasc Interv Radiol. 2010;21:1884-90.
4. Castro-Tavares J, Garrett J, Gonçalves V. Cellophane perinephritic hypertension in the dog: some biochemical, hemodynamic and pathological characteristics. Blood Vessels. 1981;18:67-74.

5. McIntosh MA, Hicks MN, Kane KA, Rankin AC, Cobbe SM. A characterized model of left ventricular hypertrophy in the rabbit. Cardioscience. 1994;5:95-100.

6. Groeneveld AE. Experimental studies in pelviureteric obstruction and hydronephrosis. Ann Acad Mad Singapore. 1984;13:571-84.

7. Bowen J, Sharma H, Gough DC. Chronic hydronephrosis: renographic drainage patterns and renal morphology in an animal model. Br J Urol. 1994;74:26-30.

\section{Correspondence:}

Silvio Tucci Jr

Faculdade de Medicina de Ribeirão Preto

Departamento de Cirurgia e Anatomia

Divisão de Urologia

Av. Bandeirantes, 3900

Campus Universitário Monte Alegre

14048-900 Ribeirão Preto - SP Brasil

Tel.: (55 16)3602-2453

stuccijr@yahoo.com.br

Conflict of interest: none

Financial source: none

${ }^{1}$ Research performed at Laboratory of Surgical Technique and Experimental Surgery, Department of Surgery and Anatomy, Faculty of Medicine of Ribeirao Preto, University of Sao Paulo (FMRP-USP). Ribeirao Preto-SP, Brazil.

Presented at XII National Congress on Experimental Surgery of the Brazilian Society for Development of Research in Surgery-SOBRADPEC, 2011 October 26-29 Ribeirao Preto-SP, Brazil. 